\title{
Population suppression of Ceratitis capitata (Wiedemann) on table grapes using toxic baits
}

\author{
CLÉBER A. BARONIO ${ }^{1,3}$, DANIEL BERNARDI ${ }^{1}$, BEATRIZ A.J. PARANHOS ${ }^{2}$, \\ FLÁVIO R.M. GARCIA ${ }^{1}$ and MARCOS BOTTON ${ }^{3}$
}

\author{
${ }^{1}$ Departamento de Fitossanidade, Faculdade de Agronomia, Universidade Federal de \\ Pelotas, Avenida Eliseu Maciel, s/n, 96010-900 Capão do Leão, RS, Brazil \\ ${ }^{2}$ Laboratório de Entomologia, Empresa Brasileira de Pesquisa Agropecuária/EMBRAPA, Embrapa \\ Semiárido, Rodovia BR-428, Km 152, s/n, Zona Rural, 56302-970 Petrolina, PE, Brazil \\ ${ }^{3}$ Laboratório de Entomologia, Empresa Brasileira de Pesquisa Agropecuária/EMBRAPA, Embrapa \\ Uva e Vinho, Rua Livramento, 515, 95701-008 Bento Gonçalves, RS, Brazil
}

Manuscript received on July 17, 2018; accepted for publication on September 21, 2018

\begin{abstract}
To provide alternatives to the use of spraying synthetic insecticides in C. capitata management, was evaluated the effect of "attract and kill" toxic baits on population suppression of $C$. capitata in three commercial areas producing table grapes. Toxic baits of $\operatorname{Gelsura}^{\mathrm{TM}}\left(4.5 \mathrm{~L} \mathrm{ha}^{-1}\right)$ and Success ${ }^{\mathrm{TM}} 0.02 \mathrm{CB}$ $\left(4.0 \mathrm{~L} \mathrm{ha}^{-1}\right)$ resulted in lower population levels of $C$. capitata adults in monitoring traps after five sequential applications at weekly intervals during the maturation period of the grapes when compared with control plots with or without insecticidal spray. In addition, plots with Gelsura ${ }^{\mathrm{TM}}$ and Success ${ }^{\mathrm{TM}} 0.02 \mathrm{CB}$ applications showed a significant reduction in damage (\%) by C. capitata on grape berries and grape bunches when compared with control plots without or with insecticidal spray. However, when compared with a plot treated by conventional management with sprays of etofenprox (Safety ${ }^{\mathrm{TM}}, 100 \mathrm{~g}$ c.p. (commercial product) $100 \mathrm{~L}^{-1}$ ) and applications of spinosad (Success ${ }^{\mathrm{TM}} 0.02 \mathrm{CB}$ toxic bait) with a brush, only Gelsura ${ }^{\mathrm{TM}}$ (4.5 $\left.\mathrm{L} \mathrm{ha}^{-1}\right)$ showed a lower level of damage of grape berries and grape bunches. Toxic baits Gelsura ${ }^{\mathrm{TM}}(4.5 \mathrm{~L}$ $\left.\mathrm{ha}^{-1}\right)$ and Success ${ }^{\mathrm{TM}} 0.02 \mathrm{CB}\left(4.0 \mathrm{~L} \mathrm{ha}^{-1}\right)$ are promising alternatives for the population suppression of $C$. capitata on table grapes.
\end{abstract}

Key words: attract-and-kill, alpha-cypermethrin, spinosad, Integrated Pest Management.

\section{INTRODUCTION}

Among the main fruits produced and exported by Brazil, table grapes (Vitis vinifera L.) grown in the Sub-medium São Francisco River Valley, located in the States of Bahia and Pernambuco, Brazil (Ferreira et al. 2010) are notable. This region is responsible for $99 \%$ of Brazil's table grape exports

Correspondence to: Daniel Bernardi

E-mail: dbernardi2004@yahoo.com.br in a cultivated area of 9,600 hectares with yields of 30 to 40 tons per hectare per year and up to two and a half harvests per year (Camargo et al. 2008, Correia et al. 2016, IBGE 2016).

The Mediterranean fruit fly (medfly) Ceratitis capitata (Wiedemann) (Diptera: Tephritidae) is one of the primary phytosanitary problems affecting the production and commercialization of fruits in the region because of direct damage that reduces both 
fruit quantity and quality (Paranhos and Gómez 2008, Morelli et al. 2012). In addition to direct damage, there are quarantine restrictions on the international trade of fresh fruit due to the presence of larvae and/or the detection of insecticide residues used for pest control (Paranhos et al. 2008, Morelli et al. 2012).

In Brazil, the management of $C$. capitata in commercial orchards involves the use of organophosphate insecticides as cover sprays that aim to control adults flying in the orchard as well eggs and larvae inside the fruits by the depth effect (Raga and Sato 2011, Botton et al. 2016). Although this management strategy has been effective for several years, the use of organophosphate insecticides has been restricted in Integrated Pest Management (IPM) due its high toxicity, longer postharvest interval (Chueca et al. 2007, Härter et al. 2015), similar to events in Europe (NavarroLlopis et al. 2013), evolution of the resistance of the C. capitata to the insecticide malathion (Magaña et al. 2007, Couso-Ferrer et al. 2011, Vontas et al. 2011, Arouri et al. 2015), besides the occurrence of population outbreaks due to the high toxicity to mites (Hardman et al. 2007, Botton et al. 2016) and deleterious effects on natural enemies (Michaud 2003, Ruiz et al. 2008, Urbaneja et al. 2009).

The management of $C$. capitata has been accomplished through the integration of different control strategies (Navarro-Llopis et al. 2015) where there is infestation, the cleaning and destruction of damaged grapes is primarily carried out during the three weeks prior to harvesting and "attract and kill" such as toxic baits and mass trapping are applied in addition to the use of insecticides spray (Raga and Sato 2005, Urbaneja et al. 2009, Cook and Fraser 2015, Botton et al. 2016).

Among the advantages of toxic baits are the absence of residues on the fruit due to the application being directed at the plants' trunk or leaves, a lower impact on natural enemies, a lower quantity of spray solution (insecticide and water) applied in the orchards, and as infestations generally originate from hosts located outside the orchards, toxic bait allows the establishment of a toxic barrier that acts to reduce infestation (Vargas et al. 2002, Navarro-Llopis et al. 2013).

The main toxic bait formulation employed in the Sub-medium São Francisco River Valley is Success ${ }^{\mathrm{TM}} 0.02 \mathrm{CB}\left(0.24 \mathrm{~g} \mathrm{~L}^{-1}\right.$ spinosad) (= GF-120) (Dow AgroSciences, Santo Amaro, São Paulo, Brazil), which contains the active ingredient spinosad (Stark et al. 2004, Mangan and Moreno 2009). Moreover, a new ready-to-use toxic bait formulation, GelsuraTM $\left(6.0 \mathrm{~g} \mathrm{~L}^{-1}\right.$ alphacypermethrin) (BASF S/A, Paulinia, São Paulo, Brazil), is currently being registered in Brazil for the management of fruit flies (Botton et al. 2016). Studies carried out in the Mediterranean region have demonstrated the potential of this formulation for the population control of Bactrocera oleae Gemlin (Diptera: Tephritidae) in olives Olea europea L. and C. capitata in citrus Citrus sinensis (L.) in Spain (Ruiz 2013).

The Gelsura ${ }^{\mathrm{TM}}$ toxic bait is composed of a polymer matrix that confers greater resistance to degradation by sunlight and rain, with $0.6 \%$ alpha-cypermethrin as the active ingredient, in addition to protein-based food attractants and a parapheromone, such as a mixture of tetra-butyl, 4-5-chloro-2-methylcyclohexane-1-carboxylate isomers, known as trimedlure (Jang et al. 2005), that is specific for the attraction of male medflies (Ruiz 2013, Vargas et al. 2018).

The Gelsura ${ }^{\mathrm{TM}}$ composition differentiates it from other toxic baits by potentiating the attractive capacity of the toxic bait to pest adults through its use in "attract and kill" or mass trapping programs based on male annihilation (El-Sayed et al. 2009, Navarro-Llopis et al. 2011, Vargas et al. 2018). Due to the need to find alternatives for the management of C. capitata in commercial crops of table grapes that can substitute for the large-scale application of cover insecticides or only one kind of toxic 
bait, the objective of this work was to evaluate the effectiveness of Gelsura ${ }^{\mathrm{TM}}$ and Success ${ }^{\mathrm{TM}} 0.02$ $\mathrm{CB}$ toxic baits in the management of $C$. capitata on table grapes in the Sub-medium São Francisco River Valley, Brazil.

\section{MATERIALS AND METHODS}

\section{EXPERIMENTAL SITES}

The experiments were carried out on farms producing table grapes (Vitis vinifera L.) in three production areas located within the municipalities of Casa Nova (BA) (9¹8’49”'S; 4052’50”W), Lagoa Grande (PE) (9॰44,8'89, 1'’S; 4080,1'75,7' $\mathrm{W}$ ) and Petrolina (PE) (9॰10'40”'S; 40³2'06”'W) using cultivars of seedless white grapes ('Sugar Crisp' and 'Arra-15'). At each farm, areas with a history of infestation by C. capitata ranging from 2.5 to 6.0 ha were selected and planted with spacing ranging from 2.0 to $3.0 \mathrm{~m}$ (between plants) $\times 3.0$ to $4.0 \mathrm{~m}$ (between rows). Previous studies have shown that C. capitata shows high levels of infestation during the maturation stage of grapes (Habibe et al. 2008, Paranhos et al. 2008), although there is infestation pressure during all months of the year.

\section{TREATMENTS}

To verify the effectiveness of $C$. capitata control in table grape production areas, two formulations of toxic baits were used: Gelsura ${ }^{\mathrm{TM}}$ and Success ${ }^{\mathrm{TM}}$ $0.02 \mathrm{CB}$ toxic baits were prepared in the proportions of 1:2 and 1:1.5 parts of commercial product and water (volume by volume, v/v), respectively. In Area 3, the insecticide etofenprox (Safety ${ }^{\mathrm{TM}}, 100$ $\mathrm{mL}$ of commercial product in $100 \mathrm{~L}$ of water $105 \mathrm{~g}$ of active ingredient in $350 \mathrm{~L} \mathrm{ha}^{-1}$ ) (Ihara, Sorocaba, São Paulo, Brazil) was used as a positive control, which is registered by the Ministry of Agriculture for the management of $C$. capitata on grapes (Agrofit 2018).

\section{FIELD EXPERIMENTS}

The experiments were conducted in three areas of table grape production. The first experiment (Area 1) was carried out in a 3.0 ha area located in Casa Nova, Bahia, Brazil, with 3-year-old grapes of the 'Sugar Crisp' cultivar (1,000 plants per hectare). Initially, this area was subdivided into three experimental plots of 1.0 ha each; Jackson traps were installed (Isca Tecnologias, Ijuí, Rio Grande do Sul, Brazil) and baited with the parapheromone trimedlure (Iscalure ${ }^{\mathrm{TM}}$ TML-plug, Isca Tecnologias, Ijuí, RS). The traps were installed at a density of four traps per hectare, and the attractant was replaced every 3 weeks (Brahman et al. 2007) to verify the occurrence and level of $C$. capitata infestation within each experimental plot during the prematuration stage and the period of physiological maturation of the grapes. The traps were positioned in two rows located in the center of the plots, one in each quadrant, equidistant from each other and suspended at the height of the grape bunches. After one week of monitoring traps to verify the occurrence of $C$. capitata in each plot, the toxic baits were applied. The treatments used included a spray solution of Gelsura ${ }^{\mathrm{TM}}$ at $4.5 \mathrm{~L} \mathrm{ha}^{-1}$ (Treatment 1), a spray solution of Success ${ }^{\mathrm{TM}} 0.02$ $\mathrm{CB}$ at $4.0 \mathrm{~L} \mathrm{ha}^{-1}$ (Treatment 2) and a negative control treatment (without the application of toxic baits or insecticide). Both toxic bait treatments were applied in five sequential applications at seven-day intervals. The toxic baits were applied using a Jacto coastal electric (Máquinas Agrícolas Jacto, Pompéia, São Paulo, Brazil) sprayer with a $15 \mathrm{~L}$ reservoir; the jets were directed (one jet every $33 \mathrm{~m}^{2}$ ) at the supporting stakes of the vineyard to form a cluster of drops at a specific point. The volume per jet of the Gelsurat ${ }^{\mathrm{TM}}$ toxic bait was $15 \mathrm{~mL}$ (4.5 $\mathrm{L} \mathrm{ha}^{-1}$ of spray solution, based on previous experiments) and Success ${ }^{\mathrm{TM}}$ $0.02 \mathrm{CB}$ toxic bait was $13.3 \mathrm{~mL}$ (4.0 $\mathrm{L} \mathrm{ha}^{-1}$ of spray solution) for a total of 300 points per hectare for both formulations. The experimental design was completely randomized. 
The second experiment (Area 2) was carried out in a 2.5 ha area located in the municipality of Petrolina, PE, with 3-year-old grapes of the 'Arra15 ' cultivar (950 plants per hectare). Initially, this study area was subdivided into two experimental plots of 1.0 hectare per plot and one plot with 0.5 hectares; Jackson traps were installed similar to Area 1. After one week of installation, the traps were monitored to verify the occurrence of $C$. capitata in each plot, the toxic baits were applied. The treatments were similar to the first experiment.

The third experiment (Area 3) was conducted in a 4.0 ha area located in the municipality of Lagoa Grande, PE, with 4-year-old grapes of the 'Arra-15' cultivar (1,150 plants per hectare). The treatments and evaluations were like the first experiment. The treatments included a spray solution of Gelsura ${ }^{\mathrm{TM}}$ $\left(4.5 \mathrm{~L} \mathrm{ha}^{-1}\right)($ Plot 1$)$ and a spray solution of Success ${ }^{\mathrm{TM}}$ $0.02 \mathrm{CB}$ (4.0 L ha ${ }^{-1}$ ) (Plot 2) applied to areas of 1.0 ha. As a control (Plot 3), or farmer treatment, the farmer sprayed etofenprox insecticide (Safety ${ }^{\mathrm{TM}}$, $100 \mathrm{~mL}$ of commercial product in $100 \mathrm{~L}$ of water $\sim 105 \mathrm{~g}$ of active ingredient in $350 \mathrm{~L} \mathrm{ha}^{-1}$ applied with a tractor sprayer) and followed this with two sequential applications of Success ${ }^{\mathrm{TM}} 0.02 \mathrm{CB}$ toxic bait $\left(2.0 \mathrm{~L} \mathrm{ha}^{-1}\right.$ of commercial product without dilution, applied with a brush on the support stakes of the vineyard). In the treatments using only toxic baits, five sequential applications were made at seven-day intervals. In the conventional plot (Plot 3), two sequential applications of etofenprox insecticide were followed by two sequential applications of spinosad (Success ${ }^{\mathrm{TM}} 0.02 \mathrm{CB}$ toxic bait); all applications occurred at seven-day intervals. The experimental design was completely randomized.

MONITORING OF C. capitata ADULTS IN THE EXPERIMENTAL AREAS

With the objective of verifying the reduction of the infestation in each plot, the evaluation of $C$. capitata populations in the experimental plots with and without applications of toxic baits was conducted weekly for six consecutive weeks after application of the treatments at 35, 28, 21, 14, 7 and $0 \mathrm{DBH}$ (days before harvest) by counting the number of male $C$. capitata captured in each trap.

\section{EVALUATION OF INJURIES IN GRAPE BUNCHES AND BERRIES}

For the evaluation of oviposition (puncture) and/or larval development (galleries) in berries and grape bunches caused by $C$. Capitata females, ten grape plants were previously selected from the two central rows of each treatment and marked with yellow tape. On each plant, 10 bunches were selected and marked with yellow tape, and the number of berries in each bunch was counted. The evaluation of damage caused by $C$. capitata was conducted at 14,7 and 0 days prior to harvest. The evaluation of the damage to each bunch in each evaluation period consisted of counting and removing damaged berries (with punctures, postures, and larvae gallery) to avoid recounting damaged berries in the following weeks. The experimental design was completely randomized with 10 repetitions (plants) per treatment, where each repetition consisted of 10 bunches of grapes in each evaluation period. The variables analyzed included the proportion (\%) of bunches damaged (calculated from the count of bunches with the presence of at least one damaged berry) and the proportion (\%) of berries damaged per bunch (calculated from the count of damaged berries and the total number of berries evaluated per bunch).

\section{DATA ANALYSIS}

Using the data obtained from the weekly capture of adult male $C$. capitata in the monitoring traps in the different treatments plots (with or without the application of toxic baits and insecticides), the number of flies per trap per day (FTD) was determined using the formula $\mathrm{FTD}=\mathrm{F} /(\mathrm{T} \times \mathrm{D})$, where $\mathrm{F}=$ the number of captured flies, $\mathrm{T}=$ number of traps in the area and 
$\mathrm{D}=$ number of days of trap exposure, according to model proposed by Navarro-Llopis et al. (2013). The data on the number of flies per trap per day (FTD) evaluated in the same week or between weeks, number of damaged berries per bunch and number of damaged bunches were subjected to a Shapiro-Wilk normality test (SPSS Inc., Chicago, IL, USA). For the residuals that did not exhibit a normal distribution or homogeneity of variance, the data were arcsinetransformed $(\sqrt{ } \mathrm{x}+0.5)$ and subsequently analyzed using an analysis of variance (ANOVA) and a means comparison (Tukey's test, $P<0.05$ ) (SPSS Inc., Chicago, IL, USA).

\section{RESULTS}

\section{MONITORING OF C. capitata ADULTS}

The application of toxic baits for suppression of C. capitata in the treatments carried out in Area 1 were effective in maintaining the level pest infestation below the control level of 0.5 flies/trap/ day (FTD) for up to $28 \mathrm{DBH}$, as recommended by Navarro-Llopis et al. (2013) (Figure 1). However, in the last two weeks ( 7 and $0 \mathrm{DBH})$, there was a population increase of $C$. capitata, particularly in the control treatment $(F=22.210 ; \mathrm{df}=23,2 ; P$ $<0.001$, FTD $=3.58)$ during the week of harvest (Figure 1). In contrast, the plots with toxic baits, Gelsura $^{\mathrm{TM}}(\mathrm{FTD}=1.50)$ and Success ${ }^{\mathrm{TM}} 0.02 \mathrm{CB}$ $($ FTD $=1.83)$, showed a smaller number of insects caught when compared $(F=12.26 ; \mathrm{df}=11,2 ; P<$ $0.001)$ to control treatment (Figure 1).

In Area 2, the application of toxic baits resulted in the suppression of infestation by adults of $C$. capitata up to $28 \mathrm{DBH}$, and during this period, Gelsura $^{\mathrm{TM}}$ and Success ${ }^{\mathrm{TM}} 0.02 \mathrm{CB}$ maintained the infestation below the control level (FTD $=0.14$ and 0.29 , respectively). At 14 and $7 \mathrm{DBH}$, there was an increase in the number of captured adults in the monitoring traps in the plots treated with Gelsura ${ }^{\mathrm{TM}}$

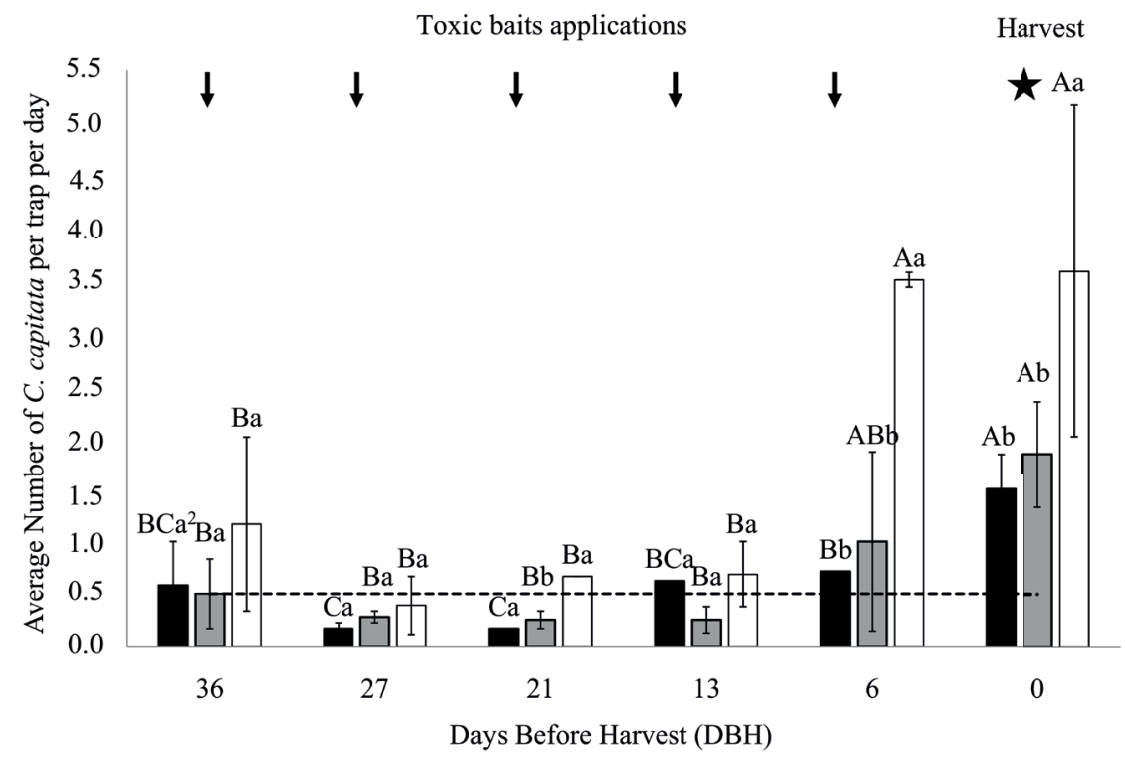

\footnotetext{
- Gelsura ${ }^{\mathrm{TM}}(4.5 \mathrm{~L} / \mathrm{ha}) \square$ Success $^{\mathrm{TM}}$ 0.02CB (4.0 L/ha) $\square$ Control treatment* --- Level control Figure 1 - Number of Ceratitis capitata captured in four Jackson traps on «Sugar Crisp〉 grapevines during the six-week evaluation period in plots with Gelsura ${ }^{\mathrm{TM}}$ toxic baits $(1: 2$ parts of water) and Success ${ }^{\mathrm{TM}} 0.02 \mathrm{CB}$ (1:1.5 parts of water). Area 1: Casa Nova, BA, February to March, 2017.

${ }^{2}$ Number of flies per trap per day (FTD) followed by equal capital letters over the course of six weeks of evaluation and by the same lowercase letters within the evaluation week do not differ (Tukey's test at $5 \%$ probability of error).

Dashed line indicates the level of control (0.5 FTD). *Control plot without the application of insecticides.
} 
$(F=26.07 ; \mathrm{df}=23,5 ; P<0.001 ;$ approximate FTD $<0.5)$, with Success ${ }^{\mathrm{TM}} 0.02 \mathrm{CB}(F=10.07 ; \mathrm{df}=23$, 5; $P<0.001$; approximate FTD $<0.6)$ and in the control treatment $(F=10.55 ; \mathrm{df}=23,5 ; P<0.001$; approximate FTD $=1.75$ ) (Figure 2). However, at 0 $\mathrm{DBH}$, the plot with toxic bait Gelsura ${ }^{\mathrm{TM}}$ applications showed a lower number of adults of $C$. capitata caught in monitoring traps $(\mathrm{FTD}=1.71)$ when compared $(F=6.34 ; \mathrm{df}=11,2 ; P<0.01)$ to control treatment, that showed a greater number of adult $C$. capitata $(\mathrm{FTD}=3.58)$, both of plots were similar to Success $^{\mathrm{TM}} 0.02 \mathrm{CB}(\mathrm{FTD}=2.25)$ (Figure 2).

In Area 3, the Gelsura ${ }^{\mathrm{TM}}$ treatment suppressed the population of $C$. capitata until $14 \mathrm{DBH}(0.75$ FTD) (Figure 3), a result that differed $(F=5.90$; $\mathrm{df}=11,2 ; P<0.05)$ from the plots treated with Success $^{\mathrm{TM}} 0.02 \mathrm{CB},(3.68$ FTD) or with application of etofenprox and Success ${ }^{\mathrm{TM}} 0.02 \mathrm{CB}$ (control treatment, 3.79 FTD) (Figure 3). However, in the last two weeks (7 and 0 DBH) there was an increase in the adult infestation pressure of $C$. capitata in the plots with the Success ${ }^{\mathrm{TM}} 0.02 \mathrm{CB}$ toxic bait $(F=9.11 ; \mathrm{df}=23,5 ; P<0.001 ; \mathrm{FTD}=15.2)$ that was greater and differed $(F=4.382 ; \mathrm{df}=11 ; P<$ $0.05)$ from the infestation observed for Gelsura ${ }^{\mathrm{TM}}$ $(\mathrm{FTD}=2.3)$ and similar the infestation observed for etofenprox + Success $^{\mathrm{TM}} 0.02 \mathrm{CB}$ (4.6 FTD at 0 DBH) (Figure 3).

\section{INJURIES IN GRAPE BUNCHES AND BERRIES}

In Area 1, the cumulative level of damage in berries showed a significant reduction $(F=17.762$; df= 29; $P<0.001)$ in the plots with applications of the toxic baits Gelsura ${ }^{\mathrm{TM}}, 0.07 \%$ ) and Success ${ }^{\mathrm{TM}} 0.02$

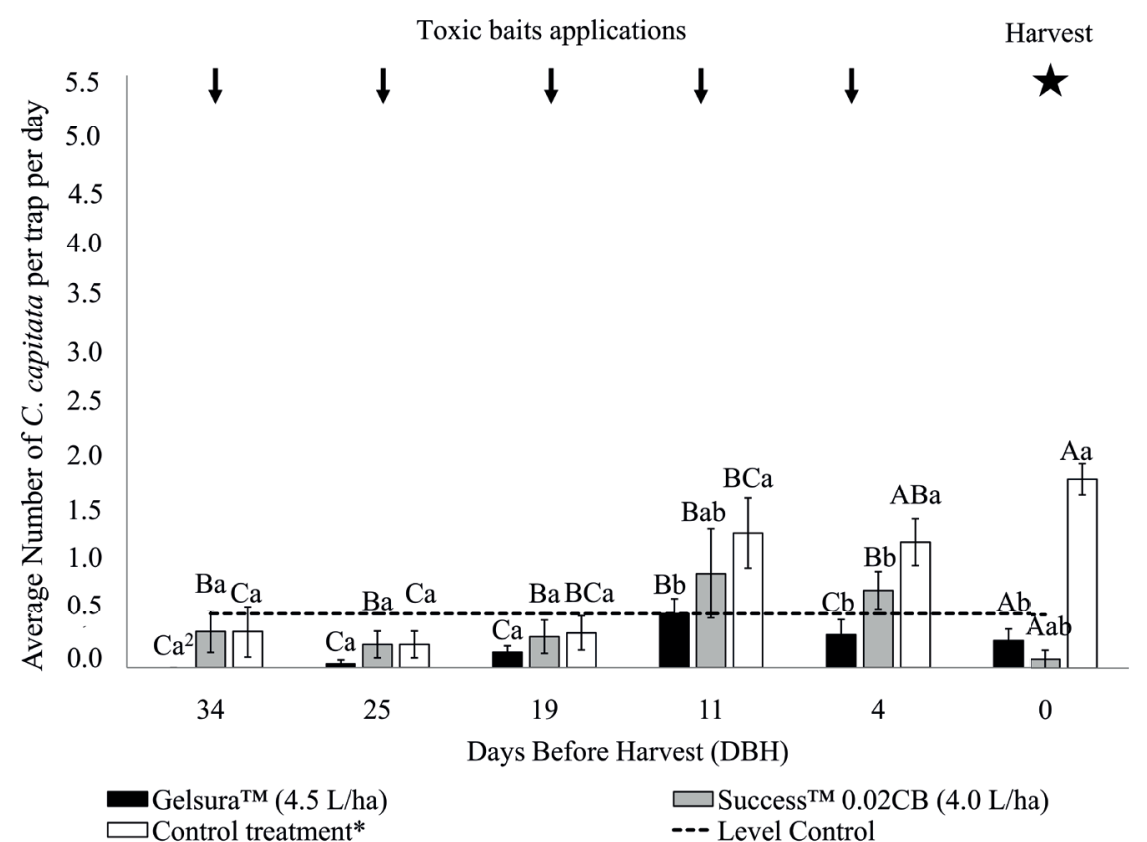

Figure 2 - Number of Ceratitis capitata captured in four Jackson traps on 〈Arra-15〉 grapevines during the six-week evaluation period in plots with Gelsura ${ }^{\mathrm{TM}}$ toxic baits (1:2 parts of water) and Success ${ }^{\mathrm{TM}} 0.02 \mathrm{CB}$ (1:1.5 parts of water). Area 2: Petrolina, PE, October/November, 2017.

${ }^{2}$ Number of flies per trap per day (FTD) followed by equal capital letters over the course of six weeks of evaluation and by the same lowercase letters within the evaluation week do not differ (Tukey's test at $5 \%$ probability of error).

Dashed line indicates the level of control (0.5 FTD). *Control plot without the application of insecticides. 
CB (0.04\%) compared with the control treatment $(0.71 \%)$ (Table I). Regarding the proportion of bunches with damage, the experimental plots with the application of the toxic baits Gelsura ${ }^{\mathrm{TM}}(2.77 \%$ of bunches damaged) and Success ${ }^{\mathrm{TM}} 0.02 \mathrm{CB}$ (2.7\% of bunches damaged) were significantly less damaged $(F=8.255 ; \mathrm{df}=29 ; P<0.001)$ compared with the control treatment $(16.0 \%$ of bunches damaged) (Table I).

In Area 2, the highest cumulative average of berries damaged by $C$. capitata over the evaluation time was observed in bunches of table grapes in the control treatment plot $(1.68 \%)$, which was significantly higher $(F=9.049 ; \mathrm{df}=29 ; P<0.001)$ than the damage observed in the plots receiving of toxic baits $\left(\right.$ Gelsura $^{\mathrm{TM}}, 0.15 \%$ and Success ${ }^{\mathrm{TM}} 0.02$ $\mathrm{CB}, 0.36 \%$ ) (Table II). In addition, the experimental plots receiving toxic baits $\left(\right.$ Gelsura $^{\mathrm{TM}}, 6.0 \%$ of bunches damaged and Success ${ }^{\mathrm{TM}} 0.02 \mathrm{CB}, 8.0 \%$ of bunches damaged) were a significantly $(F=5.400$; $\mathrm{df}=29 ; P<0.001)$ lower proportion of damaged bunches compared to the control treatment $(25 \%$ of bunches damaged) (Table II).

In Area 3, there was no significant difference $(F=3.184 ; \mathrm{df}=29 ; P<0.05)$ in cumulative damage between treatments receiving Gelsura ${ }^{\mathrm{TM}}$ toxic bait $\left(0.22 \%\right.$ of berries damaged), Success ${ }^{\mathrm{TM}}$ $0.02 \mathrm{CB}$ toxic bait ( $1.0 \%$ of berries damaged) and the conventional treatment with two applications of etofenprox and Success ${ }^{\mathrm{TM}} 0.02 \mathrm{CB}$ toxic bait ( $0.58 \%$ of berries damaged) (Table III). In addition, there was no significant difference $(F=1.020$; df $=$ $29 ; P>0.05)$ in the proportion of bunches damaged between the toxic baits Gelsura ${ }^{\mathrm{TM}}(10 \%$ of bunches

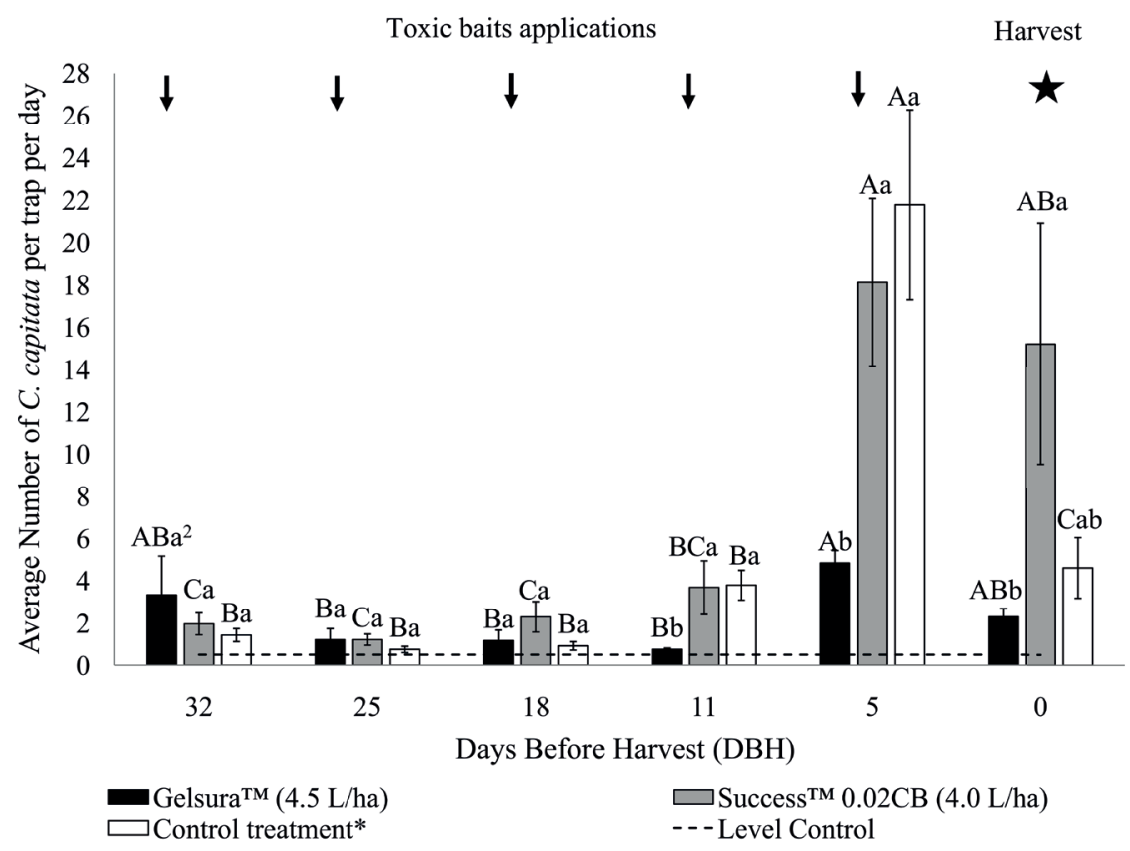

Figure 3 - Number of Ceratitis capitata captured in four Jackson traps on 〈Arra-15〉 grapevines during the six-week evaluation period in plots with Gelsura ${ }^{\text {TM }}$ toxic baits $(1: 2$ parts of water) and Success ${ }^{\mathrm{TM}} 0.02 \mathrm{CB}$ (1:1.5 parts of water). Area 3: Lagoa Grande, PE, November/December, 2017.

${ }^{2}$ Number of flies per trap per day (FTD) followed by equal capital letters over the course of six weeks of evaluation and by the same lowercase letters within the evaluation week do not differ (Tukey's test at $5 \%$ probability of error).

Dashed line indicates the level of control (0.5 FTD). *Control plot with the application of insecticides. 
damaged), Success ${ }^{\mathrm{TM}} 0.02 \mathrm{CB}$ (25\% of bunches damaged) and conventional plot with etofenprox + Success $^{\mathrm{TM}} 0.02 \mathrm{CB}$ applications $(17 \%$ of bunches damaged) (Table III).

\section{DISCUSSION}

In all the evaluated areas, the application of toxic baits was performed when the medfly infestation was low on traps (FTD between 0 and 1.86), approximately 65 days after the plants were pruned. Given that the phenological cycle of the evaluated cultivars in the region is between 100 and 120 days after pruning and that green berries are inadequate for the development of the insect (Habibe et al. 2008), the greatest infestations of $C$. capitata were observed approximately 90 to 100 days after pruning (between 21 and 14 days before harvest), when there is a greater availability of mature fruits and a greater demand by adult insects
(Habibe et al. 2008, Paranhos et al. 2008), so it is necessary to employ special attention because of the great conditions of ripe berries provide the insects biotype. This was confirmed in all areas; the incidence of $C$. capitata increased significantly in the three weeks prior to harvest $(14,7$ and $0 \mathrm{DBH})$ in all the studied areas, when most infestations above the FTD established for a control of 0.5 were recorded.

The use of toxic baits is an essential tool for the control of adult medflies in substitution for or in combination with the spraying of insecticides (Navarro-Llopis et al. 2013). In this study, it was observed that the adult population recorded in the Jackson monitoring traps baited with the Iscalure $^{\mathrm{TM}}$ TML-plug parapheromone was lowest in areas treated with Gelsura ${ }^{\mathrm{TM}}$ than Success ${ }^{\mathrm{TM}}$ $0.02 \mathrm{CB}$. This may be related to the formulation of the bait because Gelsura ${ }^{\mathrm{TM}}$ consists of a polymer matrix containing food attractants (Ruiz 2013)

TABLE I

Average number ( $\mathrm{n} \pm$ standard error) and percentage $(\%)$ of berries and bunches of table grapes of the 'Sugar Crisp' cultivar containing damage by Ceratitis capitata over three weeks of evaluations. Casa Nova, BA (Area 1).

\begin{tabular}{|c|c|c|c|c|c|c|}
\hline \multirow{2}{*}{ Treatment } & \multirow{2}{*}{ Dose $\left(\mathrm{L} \mathrm{ha}^{-1}\right)$} & \multicolumn{2}{|c|}{ Berries damaged } & \multirow{2}{*}{$\%$} & \multicolumn{2}{|c|}{ Bunches damaged } \\
\hline & & Berries $^{1}$ & $\mathbf{n} \pm \mathbf{S E}^{\mathbf{2}}$ & & $\mathbf{n} \pm \mathbf{S E}^{2}$ & $\%$ \\
\hline Gelsura $^{\mathrm{TM}}$ & 4.5 & $62.7 \pm 0.86$ & $0.60 \pm 0.31 \mathrm{~b}$ & 0.07 & $0.27 \pm 0.25 \mathrm{~b}$ & 2.7 \\
\hline Success $^{\mathrm{TM}} 0.02 \mathrm{CB}$ & 4.0 & $59.4 \pm 0.73$ & $0.90 \pm 0.38 b$ & 0.07 & $0.27 \pm 0.19 b$ & 2.7 \\
\hline Control* & - & $59.0 \pm 0.55$ & $6.40 \pm 1.14 \mathrm{a}$ & 0.71 & $1.60 \pm 0.29 \mathrm{a}$ & 16.0 \\
\hline
\end{tabular}

${ }^{1}$ Average number $(n)$ of berries evaluated in each bunch in each treated plot.

${ }^{2}$ Number of berries/bunch and bunches with damage followed by the same letter in the column do not differ (Tukey's test at $5 \%$ probability of error).

*Control plot without the application of insecticides.

TABLE II

Average number ( $\mathrm{n} \pm$ standard error) and percentage $(\%)$ of berries and bunches of table grapes of the 'Arra-15' cultivar containing damage by Ceratitis capitata over three weeks of evaluations. Petrolina, PE (Area 2).

\begin{tabular}{|c|c|c|c|c|c|c|}
\hline \multirow{2}{*}{ Treatment } & \multirow{2}{*}{ Dose $\left(\mathrm{L} \mathrm{ha}^{-1}\right)$} & \multicolumn{2}{|c|}{ Berries damaged } & \multirow{2}{*}{$\%$} & \multicolumn{2}{|c|}{ Bunches damaged } \\
\hline & & Berries $^{1}$ & $\mathbf{n} \pm \mathbf{S E}^{2}$ & & $\mathbf{n} \pm \mathbf{S E}^{2}$ & $\%$ \\
\hline Gelsura $^{\mathrm{TM}}$ & 4.5 & $44.9 \pm 2.3$ & $0.70 \pm 0.26 b$ & 0.15 & $0.60 \pm 0.22 b$ & 6.0 \\
\hline Success $^{\mathrm{TM}} 0.02 \mathrm{CB}$ & 4.0 & $43.9 \pm 2.3$ & $1.60 \pm 0.64 b$ & 0.36 & $0.80 \pm 0.33 b$ & 8.0 \\
\hline Control* & - & $43.2 \pm 1.6$ & $7.10 \pm 1.92 \mathrm{a}$ & 1.68 & $2.50 \pm 0.67 \mathrm{a}$ & 25.0 \\
\hline
\end{tabular}

${ }^{1}$ Average number $(n)$ of berries evaluated in each bunch in each treated plot.

${ }^{2}$ Number of berries/bunch and bunches with damage followed by the same letter in the column do not differ (Tukey's test at $5 \%$ probability of error).

*Control plot without the application of insecticides. 
TABLE III

Average number ( $\mathrm{n} \pm$ standard error) and percentage $(\%)$ of berries and bunches of table grapes of the 'Arra-15' cultivar containing damage by Ceratitis capitata over three weeks of evaluations. Lagoa Grande, PE (Area 3).

\begin{tabular}{|c|c|c|c|c|c|c|}
\hline \multirow{2}{*}{ Treatment } & \multirow{2}{*}{ Dose $\left(\mathrm{L} \mathrm{ha}^{-1}\right)$} & \multicolumn{2}{|c|}{ Berries damaged } & \multirow{2}{*}{$\%$} & \multicolumn{2}{|c|}{ Bunches damaged } \\
\hline & & Berries $^{1}$ & $\mathbf{n} \pm \mathbf{S E}^{2}$ & & $\mathbf{n} \pm \mathbf{S E}^{2}$ & $\%$ \\
\hline Gelsura $^{\mathrm{TM}}$ & 4.5 & $65.5 \pm 3.55$ & $1.40 \pm 0.48 b$ & 0.22 & $1.00 \pm 0.39 \mathrm{a}$ & 10 \\
\hline Success $^{\mathrm{TM}} 0.02 \mathrm{CB}$ & 4.0 & $69.1 \pm 0.95$ & $6.80 \pm 2.19 \mathrm{a}$ & 1.00 & $2.50 \pm 0.75 \mathrm{a}$ & 25 \\
\hline Control* & - & $62.0 \pm 1.46$ & $3.70 \pm 1.07 \mathrm{ab}$ & 0.58 & $1.70 \pm 0.40 \mathrm{a}$ & 17 \\
\hline
\end{tabular}

${ }^{1}$ Average number $(n)$ of berries evaluated in each bunch in each treated plot.

${ }^{2}$ Number of berries/bunch and bunches with damage followed by the same letter in the column do not differ (Tukey's test at $5 \%$ probability of error).

*Control plot with the application of insecticides.

and the parapheromone trimedlure and therefore allows greater control of the males, which reduces the population in the traps, as well as Success ${ }^{\mathrm{TM}}$ $0.02 \mathrm{CB}$. Gelsura ${ }^{\mathrm{TM}}$ has shown promising results in Europe for the control of $C$. capitata and $B$. oleae in the crops of $C$. sinensis and O. europea, respectively (Ruiz 2013).

The five sequential applications of Gelsura ${ }^{\mathrm{TM}}$ at seven-day intervals starting at 35 days prior to harvesting at the beginning of the infestations maintained the infestation of medfly adults at lower or equal levels relative to the Success ${ }^{\mathrm{TM}} 0.02 \mathrm{CB}$, and at levels equal or less than the conventional management with or without sprays (control). One variable to be evaluated in future studies is an increase in the interval between applications because in this region precipitation is low (Lopes et al. 2017). However, due to the incident sunlight, there may be greater degradation of the active ingredient, and this should be quantified to enhance the effectiveness of the applications (Allen et al. 2015). In this way, work is being done to evaluate the residual effect of these toxic baits and resistance to rainfall to $C$. capitata control.

In the areas of table grape cultivation in the Sub-medium São Francisco River Valley, conventional management includes use of toxic baits and spraying etofenprox (Safety ${ }^{\mathrm{TM}}$ ) and acetamiprid (Mospilan ${ }^{\mathrm{TM}}$ ) or the mixture of both $\left(\right.$ Eleitto $^{\mathrm{TM}}$ ) because they are the primary products accepted in the European community, which is the destination of the produce, and they are authorized for pest management in cultivated areas (EFSA 2017). However, due to restrictions in the consumer market for products without chemical residues, the use of toxic baits such as Success ${ }^{\mathrm{TM}} 0.02 \mathrm{CB}$ and Gelsura $^{\mathrm{TM}}$ allows the adequate management of $C$. capitata without contamination of the grapes with insecticide residues (Botton et al. 2016).

The medfly is in the process of adapting to the cultivation of the region (Habibe et al. 2008, Paranhos and Gómez 2008). However, even with the relatively low level of crop damage, the presence of $C$. capitata populations in the vineyards presents a problem for the export of in natura grapes to certain markets due to quarantine restrictions (Botton et al. 2016). In relation to the damage caused by oviposition puncture, even a low percentage of damaged berries (less than 2\% $\sim \pm 9.2$ damaged berries on 100 bunches), the presence of this lesion may result in an increase in the incidence of grapevine diseases as observed with A. fraterculus (Machota Jr. et al. 2016), resulting in higher production costs due to the labor required to clean the bunches (Paranhos et al. 2008, Roditakis et al. 2008). These factors, together with the problem of agrochemical residues in the fruits, make this insect one of the main impediments to the production table grapes in the region. 
Based on the results of these experiments, the 'attract and kill' technology of the alphacypermethrin-based toxic bait (Gelsura ${ }^{\mathrm{TM}}$ ) is a tool for the population suppression of $C$. capitata in grape culture that is equivalent to the Success ${ }^{\mathrm{TM}}$ $0.02 \mathrm{CB}$ toxic bait that is based on spinosad, allowing the rotation of active ingredients. Both formulations reduced pest infestation compared with a control and they are equivalent to the effectiveness of the conventional management currently employed in the region with the spraying of etofenprox (Safety ${ }^{\mathrm{TM}}$ ) with or without the use of toxic baits, wish ranging from U\$ 60.0 to 71.0 while the only use of five applications of Success ${ }^{\mathrm{TM}}$ $0.02 \mathrm{CB}$ (1.6 $\mathrm{L} \mathrm{ha}^{-1}$ of commercial product) costs about U\$ 134.3 per season. In this work, Gelsura ${ }^{\mathrm{TM}}$ proved to be efficient as well as Success ${ }^{\mathrm{TM}} 0.02 \mathrm{CB}$ and these technologies can be used in replacement or in the decrease of insecticides spraying and helps to maintain the population of $C$. capitata without causing significant damages in table grapes.

\section{ACKNOWLEDGMENTS}

The first author gratefully acknowledges the Conselho Nacional de Desenvolvimento Científico e Tecnológico (CNPq) for a doctoral scholarship supporting research funding.

\section{REFERENCES}

AGROFIT - SISTEMA DE AGROTÓXICOS FITOSSANITÁRIOS. 2018. Sistema de agrotóxicos fitossanitários. Disponível em: http://extranet.agricultura. gov.br/agrofit_cons/principal_agrofit_cons. Acesso em Julho de 2016.

ALLEN G, HALSALL CJ, UKPEBOR J, PAUL ND, RIDALL G AND WARGENT JJ. 2015. Increased occurrence of pesticide residues on crops grown in protected environments compared to crops grown in open field conditions. Chemosphere 19: 1428-1435.

AROURI R, LE-GOFF G, HEMDEN H, NAVARRO-LLOPIS V, M'SAAD M, CASTANERA P, FEYEREISAN R, HERNANDEZ-CRESPO P AND ORTEGO F. 2015. Resistance to lambda-cyhalothrin in Spanish field Populations of Ceratitis capitata and metabolic resistance mediated by $\mathrm{P} 450$ in a resistant strain. Pest Manag Sci 71: 1281-1291.
BOTTON M, ARIOLI CJ, MACHOTA-JR R, NUNES MZ AND ROSA JM. 2016. Moscas-das-frutas na fruticultura de clima temperado: situação atual e perspectivas de controle através do emprego de novas formulações de iscas tóxicas e da captura massal. Agropec Catarinense 29: 103-108.

BRAHMAN M, PASQUALINI E AND NCIRA N. 2007. Efficacy of kaolin, spinosad and malathion against Ceratitis capitata in Citrus orchards. Bull Insectology 60: 39-47.

CAMARGO UA, PROTAS JFS AND MELLO LMR. 2008. Grape growing and processing in Brazil. Acta Hort 785: 51-57.

CHUECA P, MONTÓN H, RIPOLLÉS JL, CASTAÑERA P, MOLTÓ E AND URBANEJA A. 2007. Spinosad bait treatments as alternative to malathion to control the mediterranean fruit fly Ceratitis capitata (Diptera: Tephritidae) in the Mediterranean Basin. J Pestic Sci 32: 407-411.

COOK DC AND FRASER RW. 2015. Erradication versus control of Mediterranean fruit fly in Western Australia. Agric For Entomol 17: 173-180.

CORREIA KC, SILVA MA, DE MORAIS JR MA, ARMENGOL J, PHILLIPS AJL, CÂMARA MPS AND MICHEREFF SJ. 2016. Phylogeny, distribution and pathogenicity of Lasiodiplodia species associated with dieback of table grape in the main Brazilian exporting region. Plant Pathol 65: 92-103.

COUSO-FERRER F, AROURI R, BEROIZ B, PERERA N, CERVERA A, NAVARRO-LLOPIS V, CASTAÑERA P, HERNÁNDEZ-CRESPO P AND ORTEGO F. 2011. Cross-resistance to insecticides in a Malathion-resistant strait of Ceratitis capitata (Diptera: Tephritidae). J Econo Entomol 104: 1349-1356.

EFSA - EUROPEAN FOOD SAFETY AUTHORITY. 2017. Review of the existing maximum residue levels for etofenprox according to Article 12 of Regulation (EC) No 396/2005. Available at: http://onlinelibrary.wiley.com/ doi/10.2903/j.efsa.2017.4964/full. Accessed on February, 2018.

EL-SAYED AM, SUCKLING DM, BYERS JA, JANG EB AND WEARING CH. 2009. Potential of "Lure and Kill" in long-term pest management and eradication of invasive species. J Econ Entomol 102: 815-835.

FERREIRA MDP, LIRIO VS AND MENDONÇA TG. 2010. Análise do perfil e grau de incidência de barreiras não-tarifárias sobre as exportações brasileiras de frutas selecionadas. Revista Econômica do Nordeste 41: 683-698.

HABIBE TC, VIANA RE, NASCIMENTO AS, PARANHOS BAJ, HAJI FNP, CARVALHO RS, DAMASCENO IC AND MALAVASI A. 2008. Infestação de Uva, Vitis vinifera pela Mosca-do-Mediterrâneo, Ceratitis capitata (Wiedemann) no Submédio do Vale do São Francisco. Fruit Flies of Economic Importance: From Basic to Applied Knowledge. Salvador, Brazil: Proceedings of $7^{\text {th }}$ International Symposium on Fruit Flies of Economic Importance, p. 183-185. 
HARDMAN JM, FRANKLIN JL, BEAULIEU F, BOSTANIAN NJ. 2007. Effects of acaricides, pyrethroids and predator distributions on outbreaks of Tetranychus urticae in apple orchards. Exp Appl Acarol 43: 235-253.

HÄRTER WR, BOTTON M, NAVA DE, GRUTZMACHER AD, GONÇALVES RS, MACHOTA JR R, BERNARDI D AND ZANARDI OZ. 2015. Toxicities and residual effects of toxic baits containing Spinosad or Malathion to control the adult Anastrepha fraterculus (Diptera: Tephritidae). Fla Entomol 98: 202-208.

IBGE - INSTITUTO BRASILEIRO DE GEOGRAFIA E ESTATÍSTICA. 2016. Sistema IBGE de Recuperação Automática (SIDRA). Disponível em: https://sidra.ibge. gov.br/home/pms/brasil. Acesso em 25 de Março de 2016.

JANG EB, KHRIMIAN A, HOLLER TC, CASANA-GINER V, LUX S AND CARVALHO LA. 2005. Field response of Mediterranean fruit fly (Diptera: Tephritidae) to Ceralure B1: evaluations of enantiomeric B1 ratios on fly captures. J Econ Entomol 98: 1139-1143.

LOPES I, GUIMARÃES MJH, MELO JMM AND RAMOS CMC. 2017. Balanço hídrico em função de regimes pluviométricos na região de Petrolina-PE. Irriga 22: 443457.

MACHOTA JR R, BORTOLI LC, CAVALCANTI FB, BOTTON M AND GRÜTZMACHER AD. 2016. Assessment of injuries caused by Anastrepha fraterculus (Wied.) (Diptera: Tephritidae) on the incidence of bunch rot diseases in table grape. Neotrop Entomol 45: 361-368.

MAGAÑA C, HERNÁNDEZ-CRESPO P, ORTEGO AND CASTAÑERA P. 2007. Resistance to malathion in field populations of Ceratitis capitata. J Econ Entomol 100: 1836-1843.

MANGAN RL AND MORENO AMT. 2009. Honeybee foraging preferences, effects of sugars and fruit fly toxic bait components. J Econ Entomol 102: 1472-1481.

MICHAUD JP. 2003. Toxicity of fruit fly baits to beneficial insects in citrus. J Insect Sci 3: 1-9.

MORELLI R, PARANHOS BAJ AND COSTA MLZ. 2012. Eficiência de Etofenproxi e Acetamiprido no controle de mosca-do-mediterrâneo Ceratitis capitata (Diptera: Tephritidae) em pomar de manga. Bioassay 7: 1-6.

NAVARRO-LLOPIS V, ALFARO C, PRIMO J AND VACAS S. 2011. Response of two Tephritid species, Bactrocera oleae and Ceratitis capitata to different emission levels of pheromone and parapheromone. Crop Prot 30: 913-918.

NAVARRO-LLOPIS V, PRIMO J AND VACAS S. 2013. Efficacy of attract-and-kill devices for the control of Ceratitis capitata. Pest Manag Sci 29: 478-482.

NAVARRO-LLOPIS V, PRIMO V AND VACAS S. 2015. Bait station devices can improve mass trapping performance for the control of the Mediterranean fruit fly. Pest Manag Sci 71: 923-927.

PARANHOS BAJ AND GÓMEZ MP. 2008. A mosca-dasfrutas e a comercialização de frutas. Embrapa Semiárido, Petrolina. Disponível em: https://ainfo.cnptia.embrapa.br/ digital/bitstream/CPATSA-2009-09/39797/1/OPB2073. pdf. Acesso em 15 de Janeiro de 2017.
PARANHOS BAJ, NASCIMENTO AS, BARBOSA FR, VIANA R, SAMPAIO R, MALAVASI A AND WALDER JMM. 2008. Técnica do Inseto Estéril: nova tecnologia para combater a mosca-das-frutas, Ceratitis capitata, no Submédio do Vale do São Francisco. Embrapa Semiárido, Petrolina: Embrapa Semiárido, Brazil.

RAGAAAND SATO ME. 2005. Effect of spinosad bait against Ceratitis capitate (Wied.) and Anastrepha fraterculus (Wied.) (Diptera: Tephritidae) in laboratory. Neotrop Entomol 34: 815-822.

RAGA A AND SATO ME. 2011. Toxicity of neonicotinoids to Ceratitis capitata and Anastrepha fraterculus (Diptera: Tephritidae). J Plant Prot Res 51: 413-419.

RODITAKIS E, TSAGKARAKOU A AND RODITAKIS NE. 2008. Extensive damage on white variety table grapes by the Mediterranean fruit fly Ceratitis capitata (Wiedemann) in Crete. EPPO Bull 38: 216-219.

RUIZ CB. 2013. Experiencias em el control de Bactrocera oleae, Ceratitis capitata y otras plagas emergentes, em la zona mediterránea mediante técnicas de "Attract and Kill'. In: III Jornadas Internacionales sobre Feromonas, Atrayentes, Trampas y Control Biologico: Herramientas para la Gestión integrada. Murcia. Available at: https:// www.phytoma.com/images/254_feromonas_plagas emergentes.pdf. Accessed on March 7, 2016.

RUIZ L, FLORES S, CANCINO J, ARREDONDO J, VALLE J, DIAZ-FLEISCHER F AND WILLIAMS T. 2008. Lethal and sublethal effects of spinosad-based GF-120 bait on the Tephritid parasitoid Diachasmimorpha longicaudata (Hymenoptera: Braconidae). Biol Control 44: 296-304.

STARK JD, VARGAS R AND MILLER N. 2004. Toxicity of spinosad in protein bait to three economically important tephritid fruit fly species (Diptera: Tephritidae) and their parasitoids (Hymenoptera: Braconidae). J Econ Entomol 97: 911-915.

URBANEJA A, CHUECA P, MONTÓN H, PASCUAL RS, DEMBILIO D, VANACLOCHA P, ABAD-MOYANO R, PINA T AND CASTAÑERA P. 2009. Chemical alternatives to Malathion for controlling Ceratitis capitata (Diptera: Tephritidae), and their side effects on natural enemies in Spanish citrus orchards. J Econ Entomol 102: 144-151.

VARGAS RI, MILLER NW AND PROKOPY RJ. 2002. Attraction and feeding responses of Mediterranean fruit fly and a natural enemy to protein baits laced with two novel toxins, phloxine B and spinosad. Entomol Exp Appl 102: $273-282$.

VARGAS RI, SOUDER SK, RENDON P AND MACKEY B. 2018. Suppression of Mediterranean fruit fly (Diptera: Tephritidae) with trimedlure and biolure dispensers in Coffea arabica (Gentianales: Rubiaceae) in Hawaii. J Econ Entomol 111: 293-297.

VONTAS J, CRESPO PH, MARGARITOPOULOS JT, ORTEGO F, FENG HT, MATHIOPOULOS KD AND HSU JC. 2011. Insecticide resistance in Tephritid flies. Pest Biochem Phys 100: 199-205. 